\title{
Mountains talk of kings and dragons, the Brecon Beacons
}

\author{
Bernadette Brady
}

This chapter turns to the Brecon Beacons in Wales and approaches the nature of a 'place' as it draws together the diverse threads of local folklore, sky and star movements, the contemporary use of the place of the Brecon Beacons, and the location's larger cultural themes of the dragon of Wales and its links to kingship. With so many diverse layers of mythology and topography, these two twin peaks present what Belden Lane defined as a place that 'talks back', a place that participates with humanity in its expression. ${ }^{1}$ The case study slowly reveals that the roof of the Brecon Beacons, rich in its cultural roots, is a place 'singing to itself' and as such draws sacredness or meaning towards itself independent of human conscious actions.

The Brecon Beacons is a mountain range comprised of six main peaks shaped into a long winding ridge which geographically defines the border between south and mid Wales. At either end of the ridge are mountain ranges: to the west, Black Mountain; and to the east the similarly named, Black Mountains. The actual name of the Brecon Beacons is thought to relate to their use of beacon lighting to warn of attacks. The beacons were also lit to celebrate the millennium. One of these six peaks is the highest in southern Britain. Named Pen y Fan and standing at 886 metres, it is connected by a ridge to the west to the second highest peak, Corn $\mathrm{Du}$, with a height of 873 metres. The two peaks and their joining ridge thus combine to form a 'beam' in the roof of the Brecon Beacons. From this high ridge two U-shaped glacial valleys flow, one running down to the south, called the Tâf Fechan Valley, and the other to the north, containing a glacial lake, Llyn cwm Llwc (Figure 7.1, top).

From 1896 to 1902 a section of the Tâf Fechan Valley was flooded to form the Upper Neuadd Reservoir. The reservoir was built in a rectangular shape with a 

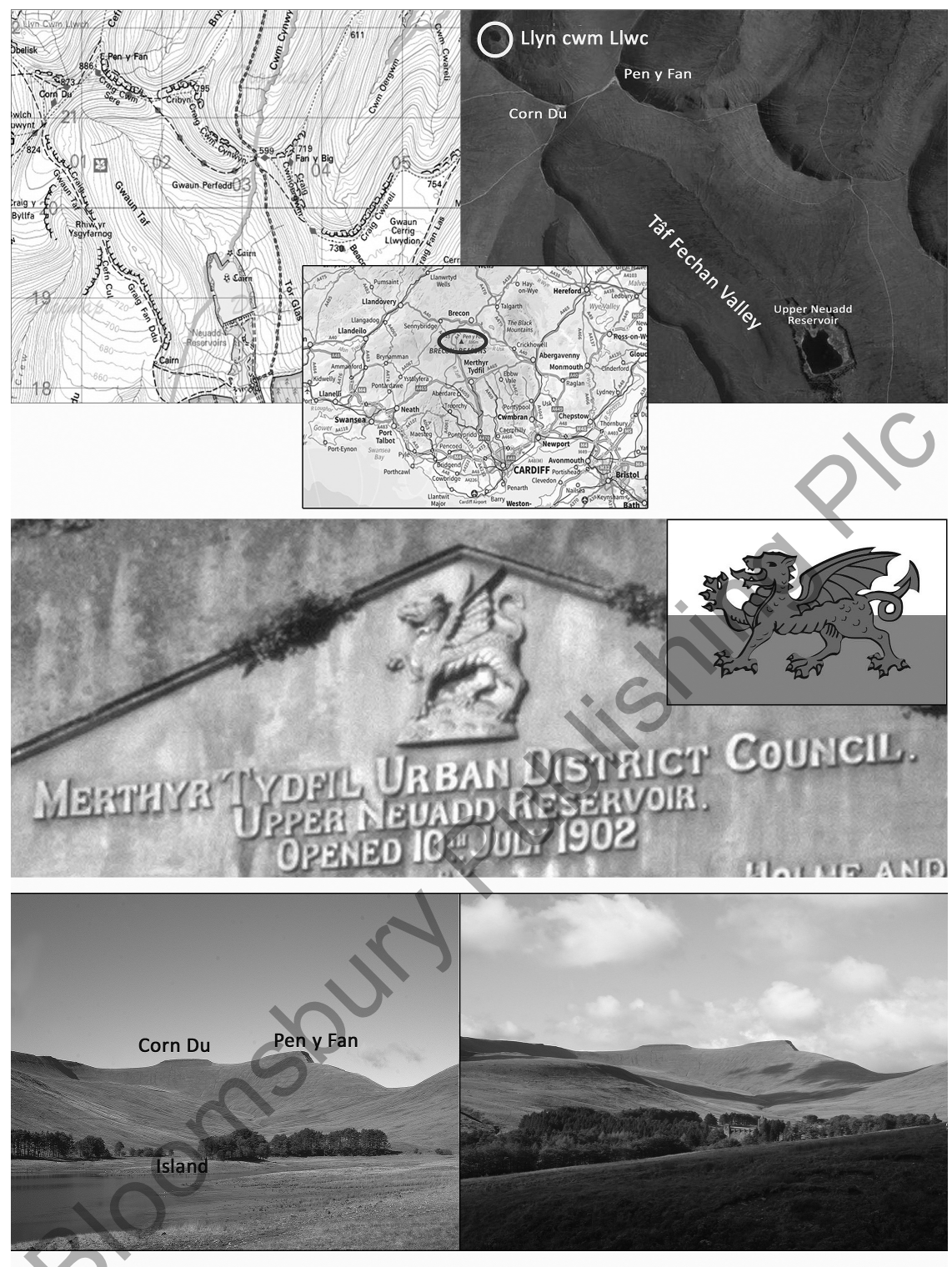

Figure 7.1 Top: Ordinance Survey map of the two valleys that flow northerly and southerly from the twin peaks of Pen y Fan and Corn Du in the Brecon Beacons, South Wales, plus the image of the same area from Google Earth showing the Upper Neuadd Reservoir, the contours of the ridge, and the small glacial lake of Llyn cwm Llwch in the top left edge of the map. Middle: The plaque on the outflow of the Upper Neuadd Reservoir, showing a Welsh Dragon image before the emblem was standardized into its national icon in 1959. Photo: B. Brady. Insert: The style of the nationalized Welsh dragon. Bottom left: The view of Cadair Arthur, looking north from the side of the Upper Neuadd Reservoir showing the island on which there is a round barrow cemetery. Bottom right: The view of Cadair Arthur from outside the valley looking north. The wall of the outflow to the Upper Neuadd Reservoir can be seen as the small structure in the middle of the image. Photos: B. Brady. 
massive outflow wall across a natural narrowing in the valley. Upon this outflow wall there is a plaque proclaiming the date of opening, 10 July 1902, and topped by a 1902 version of a Welsh dragon (Figure 7.1, middle). This is not the dragon one normally associates with Wales, for it was only in 1959 that the dragon's image took on its official Welsh form that we know today (Figure 7.1, middle insert). ${ }^{2}$

Additionally, in more recent times, the Merthyr Tydifil Angling Association has been given permission to stock the upper reservoir with wild brown trout. This area is now considered to be a premier fly-fishing area, although warnings are given that the trout are rare and extremely hard to catch, with a bag limit of only two per day. According to a fly-fishing website for the area,

Fly fishing is the only permitted method and small imitative patterns are recommended. The trout will not be large and they will not be easy to catch, but it is hard to imagine a more beautiful or more isolated place in which to fish this side of the Scottish border. ${ }^{3}$

Although the valleys are now mainly home to day trekkers and fly-fishers, these two valleys have, in the past, seen much human activity. Apocryphal stories tell of a Roman road or trail that runs through Tâf Fechan Valley over the escarpment and through to the northern side of the Beacons. Jenny Hall and Paul Sambrook Trysor pointed out, however, that there was no archaeological evidence of such a road, although they noted that there was an old trackway which crossed to one side of the Tâf Fechan Valley and this followed a stream called Nant yr Hen Heol (the Stream of the Old Road). ${ }^{4}$ Notwithstanding this lack of Roman stonework, the Tâf Fechan Valley and the high ridge between Pen y Fan and Corn Du hold substantial evidence of Neolithic and Bronze Age activity. Under or near the water of the Upper Neuadd Reservoir there are at least six cairns or round hut foundations, with some located on a natural island in the reservoir. Those on the island, according to the RCAHM in 1997, have the appearance of sepulchral cairns. ${ }^{5}$ In 2006 this entire grouping of the submerged cairns and those on the island were defined by the Clwyd-Powys Archaeological Trust as a round barrow cemetery. ${ }^{6}$ In addition to these structures, both Pen y Fan and Corn Du have round barrows on their summits, with the barrow on Pen y Fan containing a bronze horde. ${ }^{7}$ Thus the Tâf Fechan Valley with its high location and its naturally raised area of ground - the island in the reservoir was considered important and probably even sacred by Neolithic and/or Bronze Age people, a place of burial with the peak of Pen y Fan deemed worthy of the gift of a precious horde of metal. 
The story of these valleys does not end there, however. At this juncture one could, using the evidence of the ancient metal horde and the Neolithic or Bronze Age cemetery, speculate about the human-bestowed sacredness of the place. Such an argument would, of course, be complemented by the natural liminal nature of mountains for, as Christopher Tilley wrote, mountains are 'considered to be the dwelling-places of spirits and places where shamans go to practise magic. ${ }^{8}$ Yet there are other features in this high ancient burial ground. The ridge between Corn Du and Pen y Fan is orientated at a true azimuth of around $70^{\circ}$, azimuth being the compass bearing measured from due north at $0^{\circ}$. Hence the ridge creates a high horizon which runs roughly east-west. If a person stands on the raised land, which is now the island in the reservoir, and looks north to the ridge they would see a raised, clear, and well-defined level horizon line at an altitude of around $10^{\circ} .9$ As a result, the view of the stars touching the ridge is free from horizon haze, thus the circumpolar stars, the never-setting northern stars, are clear and sharp as they skim along the top of the ridge. In this way the natural liminal place of the burial ground and high mountains gains an additional feature of being a place where special stars, non-setting stars, commune with the earth. Adding to this feature is the fact that all northern hemisphere stars reach their lowest point in the sky when they are at a bearing of due north. Hence a star seen to just skim the ridge would act as a marker of the direction of due north. This feature is one of the threads of meaning in the valley, for north is linked to the mythical king of the Britons, Arthur, and indeed by coincidence the ridge and twin peaks are known as Arthur's Chair.

In 1188 Gerald of Wales, in his work Journey around Wales, focused his attention on the glacial lake in the northern valley named Llyn cwm Llwc. He defined the lake as 'miraculous' and gave its location as lying 'to the south by a range of hills the chief of which is Cadair Arthur, or Arthur's Chair, so called from two peaks which rise up in the form of a throne. ${ }^{10}$ This visual phenomenon of a chair is formed by the ridge between the peaks dipping a little below the level of the two peaks, with the peaks forming the arms of a chair (Figure 7.1, bottom). Gerald explained the link to Arthur and the throne as, 'This summit is a very lofty spot and most difficult of access, so that in the minds of simple folk it is thought to have belonged to Arthur, the greatest and most distinguished King of the Britons.'11 The name of Cadair Arthur or Arthur's Chair persisted on maps until the early twentieth century and is still so named by websites which discuss hiking in the area. This name, however, is by no means unique to these twin peaks. Thomas Green listed at least nine other places, ranging in locations from Edinburgh to Tintagel in Cornwall. Although one can make no claim as 
to which of these 'chairs' was the earliest, many of them appear to be named at dates later than the observations made by Gerald of Wales of Pen y Fan and Corn Du. ${ }^{12}$ Nevertheless, while all have similar topography of a high ridge with raised sides, they do not necessarily have an east-west orientation and thus one cannot observe the northern sky behind the chair.

Having dismissed the folk stories of Cadair Arthur, Gerald detailed the magical qualities of the peaks. He described the peak of Pen y Fan where,

On the topmost point of this mountain a spring of water bubbles forth. Its deep basin is square in shape and like a well, but no stream ever runs from it. Trout) are said to be found there from time to time. ${ }^{13}$

Gerald considered the mountain a place of magic, a notion supporting Tilley's link between high places and magic cited earlier. For Gerald, this magic was twofold, embracing the deep spring which was like a well and held water that never flowed as a stream and the periodical presence of trout in this well. Gerald then wrote of the small lake in the northern valley, Llyn cwm Llwc, to which he attributed even greater magical powers. According to Gerald, this lake could at different times turn into rich pasturelands or become adorned with gardens and an orchard, while at other times it could be covered with buildings or groan horribly when iced over. Yet its central miraculous property lay not in its shape-changing. In the time of 'the cold winter season' when waterfowl were on its surface, it had the power to recognize the true heir to the kingship of Wales. ${ }^{14}$

Gerald explained this myth through an anecdote. He recounted an earlier story of three men - Milo, Earl of Hereford (f. 1139); Gruffydd, son of Rhys ap Tewdwr (d. 1137); and Payn FitzJohn (d. 1137) - who rode by the lake when it was occupied by waterfowl. Milo challenged Gruffydd to let the birds test his claim that the blood of Welsh princes ran in his veins. Gruffydd replied that, since Milo had great power in the country, he should speak to the birds first. Yet neither Milo nor Payn could make the birds sing. When Gruffydd, however, claimed loudly that he was the true heir of the ancient Welsh throne, 'all the birds, each according to his kind, beat the water with their wings and began to sing with one accord and to proclaim him master. ${ }^{15}$ Gerald's claim was that the lake could recognize and announce the true king of Wales and the timing of such announcements was winter, when the waterfowl gathered there. This story of Welsh kingship fits seamlessly into the local name of the ridge and peaks, that of Cadair Arthur, with Arthur being, as Gerald claimed, 'the greatest and most distinguished King of the Britons'. 
Thus stories, folklore, history, and legends have gathered around these two mountains, making them a 'thick' place, one rich with meaning. Tim Ingold has argued that the construction of 'place' is where different threads meet and overlap, 'in which every linear segment serves as a joint, welding together the elements of the pattern into a totality of a higher order. ${ }^{16}$ In the case of these two mountains, the components that imply Ingold's 'totality of a higher order' are the 'welding together' of the material evidence of sacredness of burials and bronze hordes from the time of pre-history, the topographical features of liminality of the highest mountains in southern Britain, and the evidence in the literature of stories of magic, wonder, or 'otherworldliness' which are linked to the theme of Welsh kingship. These components are sufficient to produce the thick description of this location, yet to this potent place, with its emphases on winter, a starry dragon joins the blend.

\section{The Roman sky}

Celestial cartography, and thus the images within the starry sky, has been consistent in Western culture since the Greeks. The constellations of modern Western celestial cartography were enshrined in poetry by Aratus in the third century BCE:

Through the two Bears the breathtaking

Dragon meanders like a river, snaking

At great length far and wide, On either side

Of his extent, the Bears wheel with the tide

Beneath them.

These poetic images were then immortalised in the first century CE by Claudius Ptolemy in his work, the Almagest, where, for example, helocated the constellation of Draco, the Dragon, star by star in the sky, defining the position of 'the star on the tongue, the star in the mouth, the star above the eye, the star on the jaw, the star above the head', and so on, listing not only the thirty-one stars for the constellation of Draco but also their location in the constellation image and their magnitude. ${ }^{18}$ The Romans inherited these sky images from the Greeks and, as they were a useful for navigation and calendar matters, they became culturally robust. ${ }^{19}$ Indeed so culturally robust were these Greco-Roman sky images that when they encountered the well-established sky cartography of the Egyptians, the Egyptian cartography was slowly lost. ${ }^{20}$ Hence when the Romans marched 
into Wales in $77 \mathrm{CE}$, so too did their sky. ${ }^{21}$ Their sky is our sky, one where the area around the north celestial pole is encircled by the two bears, Ursa Major and Ursa Minor, with the dragon, Draco, curled between them.

Evidence that Greco-Roman cartography had been injected into the Welsh culture can be seen in the work of Geoffrey of Monmouth (c.1100-55). In his Prophecies of Merlin, he wrote of the world in chaos which he defined by zodiac constellations in disarray:

The twins shall surcease from their wonted embrace, and shall call the Urn unto the fountains. The Scales of the Balance shall hang awry until the Ram shall set his crooked horns beneath them. ${ }^{22}$

Granted, as Mark Williams pointed out, there is little to no evidence before the time of Geoffrey's work of the zodiac (and thus Greco-Roman celestial cartography) in Welsh early medieval literature. ${ }^{23}$ Nevertheless, an absence of evidence is not evidence of absence. Wales, particularly south Wales, was dominated in the first century CE by Roman culture; thus around the sixth century, at the time of the legendary kingship of Arthur, the Greco-Roman celestial cartography with its northern bears and dragon would have populated the heavens over southern Wales.

Of all the circumpolar constellations Draco traces the longest line through the sky, winding upwards and around the bears. Additionally, a feature of Draco is that at its lowest culmination, the dragon's head points directly downwards and thus its head on, or near, the ground indicates due north. At the latitude of the valley $\left(51^{\circ} \mathrm{N} 53^{\prime} 1.8^{\prime \prime}\right)$, if one stands in the mouth of the valley, or even further away, and looks towards Cadair Arthur, the sky dragon will appear to butt its head on or just above the horizon of the ridge, near the peak of Pen y Fan (Figure 7.2, left). The constellation Draco has maintained this visual orientation despite the effects of precession, the slow shift of the stars against the seasons, over the last few thousand years. Precession is slowly lowering the dragon's head onto the ridge; however, in the course of the last 3,500 years, the head of Draco has only lowered by $4^{0}$, with little change to the actual time of the year when this is seen.

The actual nights when Draco will be seen at its lowest culmination and engaging with Arthur's Chair will depend on the time of the year. Gerald commented that the waterfowl that could proclaim the king gathered on this high-altitude lake in 'the cold winter season'. For the Bronze Age, and in Gerald's time, and for today, Draco will only be seen with its head on the ridge during the nights of the winter months (Figure 7.2). This annual rhythm forms a 

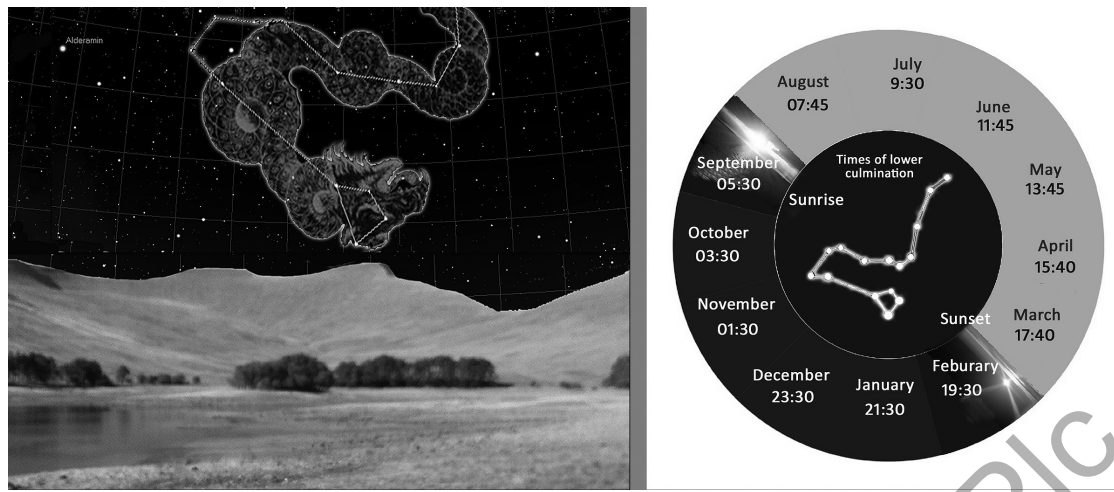

Figure 7.2 Left: An artistic rendition of Draco at its lower culmination for $1000 \mathrm{CE}$ (indicating due north) over Cadair Arthur from a location adjacent to the reservoir. Image: B. Brady. Right: The local mean times to the nearest five minutes of the lower culmination of Draco for the year $1000 \mathrm{CE}$ for the fifteenth day of each month (Gregorian calendar). The night hours are dark, while the daylight hours are light. Draco's lower culmination is only visible in the nights of the winter months. This pattern is still applicable today. Image: B. Brady.

correlation with Gerald's discussion of the magical Llyn cwm Llwc which could only proclaim a Welsh king in the winter months. Draco can only be seen to 'sit' in Arthur's Chair in nights of the winter months.

\section{The dragon in Wales}

As the Romans colonized Britain, and later Wales, they brought with them the image of the dragon as an icon of military might. As noted by Pat Southern and Karen R. Dixon, it was in the second century CE that Roman cavalry adopted the draco standard. This standard was a dragon represented as a flaglike banner that flowed from the top of a pole but in the shape of a windsock so it could capture the air and, at times, even makes sounds. ${ }^{24}$ John Tatlock commented that the dragons of these Roman forces were either coloured red or purple and were used not only in warfare but also in ceremonial ways. ${ }^{25}$ As the Roman legions and cavalry moved across Britain, they introduced the notion of the dragon as a creature of the air and of military might which should be feared.

Evidence for the Welsh adoption of the dragon stands, according to Tatlock, on uncertain ground. ${ }^{26}$ Nevertheless, the dragon within Welsh or early British culture was viewed in a positive manner and linked to kingship and military 
might. In the sixth century the monk, Gildas (c.500-70) wrote a work named De Excidioi Britanniae (Ruin of Britain). This work Ronald Hutton considered to be 'the nearest thing that we possess to an account of the sub-Roman period in Britain written by somebody who was part of it. ${ }^{27}$ In this work Gildas gave his opinion of a welsh king, Maglocune, who is believed to be Maelgwn Gwynedd, king of north Wales, and Gildas spoke of him as 'O thou dragon of the island' and then referred to him as 'exceeding many in power' in his role of kingship. ${ }^{28}$ Furthermore, the Historia Brittonum, a work of around $800 \mathrm{CE}$ considered to be authored by the Welsh monk, Nennius, described a Red Dragon as the symbol of the British people in their wars against the White Dragon of the Saxons. He wrote of a dream or vision of the two dragons fighting within a pool,

The pool is the emblem of this world, and the tent that of your kingdom: the two serpents are two dragons; the red serpent is your dragon, but the white serpent is the dragon of the people who occupy several provinces and districts of Britain. ${ }^{29}$

Such accounts reinforce the view that the Welsh linked the dragon to their own fighting identity against the invading Saxons.

This Welsh association with the dragon and its link to a warrior king offers an insight into why the Welsh alone in all of Europe maintained a positive view of the dragon. In other parts of Europe the dragon fell victim to the Christian Book of Revelation and became an evil creature associated with Satan. ${ }^{30}$ Hutton argued that in the Early Middle Ages the dragon throughout most of Europe was considered a 'fire-breathing, flying reptilian monster' which carried off livestock; yet, Hutton continued, such an evil creature, in this difficult guise, did not exist in Celtic Britain. ${ }^{31}$ The dragon as warrior king was instilled in British/Welsh culture quite early and may have been adopted or copied from the Romans. It would have then been reinforced in the Welsh culture as they fought against other invading tribes and thus wellestablished before the arrival of Christianity with its Book of Revelation in the sixth century.

For Celtic Britain, the dragon's kingly association is with Arthur and his father. In the poetic history of Geoffrey of Monmouth, the source of most of the Arthurian legendary material, it is not surprising that Geoffrey named Arthur's father as Uther Pendragon, where 'pendragon' means head dragon. ${ }^{32}$ Arthur's birth was also, according to Geoffrey, foretold by the appearance of the Dragon Star, a type of Celtic star of Bethlehem, which appeared in the sky in the shape of two dragons. Additionally, in the medieval Welsh manuscript the Mabinogi, the Dream of Rhonabwy, Arthur's sword is described as two fire-breathing serpents 
that, when unsheathed, produced 'two flames of fire, so dreadful that it was not easy for anyone to look'. He, Arthur, also sat upon 'a chair so large that three armed warriors could sit in it' while he was wrapped in a mantle that bestowed on its wearer the ability to see everyone while being unseen by all. ${ }^{33}$ Tatlock also pointed out that Arthur wore a golden helmet sculptured as simulacro draconis. ${ }^{34}$ All of these attributes have strong sky components: the Dragon Star, huge high seats where all can be seen, and a golden helmet which could be a reference to the sun. Hutton suggested that it is entirely possible that the notion of Arthur was a humanization of a 'pagan god, probably of the sun, who was turned into a human hero after the coming of Christianity. ${ }^{35} \mathrm{He}$ added the caveat, however, that nineteenth-century authors had the tendency to link mythic heroes to forces of nature. Nevertheless, Green made the case that the name Arthur had its origins in the Gallo-Brittonic arto- 'bear, warrior and hero' and he defined Arthur as

a story-cycle focused on a folkloric Protector of Britain and a peerless warrior, a character of local wonder-tales and the wild parts of the landscape who is intimately connected with the Otherworld. ${ }^{36}$

Green noted that the bright star in the northern hemisphere, Arcturus, carries the proper name made of the Greek arktos, 'bear' + ouros, 'guardian, keeper' meaning guardian of the bear, or guardian of the north, thus adding to the star or sky theme of Arthur and the dragon. ${ }^{37}$ Further links between Arthur and the north are seen in an alternative name for Ursa Major as being Arthur's Wain. ${ }^{38}$ Finally there is the fact that the word 'bear' was also used in the Greek to indicate the north. ${ }^{39}$ Whether Arthur was a real figure or a sky phenomenon or a combination of both, it is generally accepted that among his attributes are the dragon, links to the north, and a tendency to dwell in high places, or liminal areas, thereby maintaining his otherworldliness.

These links of the north, Welsh kingship, and dragons all reside in the twin summits of the Brecon Beacons. At a local level the area's folklore of kingship is in rapport or enhanced by the sky's movement against the local landscape, as it places the constellation of Draco on the ridge only in the winter months. These local stories are, however, moved into a national sphere through the ethnotopography of the ridge being acknowledged as Cadair Arthur, the lost king of the Welsh. Arthur's attributes, whether consciously understood or not, are also supplied by the northern view provided by the high ridge and the Welsh symbol of the dragon visible sitting on the great king's throne, Arthur's Chair. 


\section{The power of place}

In contemporary thought landscapes tends to be viewed as inert in that it is a place upon which humanity acts. Tilley, however, suggested that such storied landscapes become humanized and encultured as they become saturated with place names which are intertwined with topography and human intentionality and even mythological characters. ${ }^{40}$ To this idea of intertwined intentions and landscape the classical notion of place as presented by Aristotle (384 BCE-322 BCE) gains relevance. Aristotle defined place as coextensive with its occupying body, like a vessel that gives shape to water but is independent of that water. ${ }^{41}$ Edward Casey argued that this Aristotelian approach viewed place as holding its own quality independent of its contents. ${ }^{42} \mathrm{He}$ expanded his comments on Aristotle's view of place by stating,

This is the acknowledgment of place as a unique and nonreducible feature of the physical world, something with its own inherent powers, a pre-metric phenomenon (thus both historically and conceptually pre-Euclidean in its specification). And above all something that reflects the situation of being in, and moving between, places. ${ }^{43}$

It is this very notion of motion, moving between places, that Aristotle ascribed to the power of place. He argued that the motion of any body, which was composed of the natural elements of fire, earth, air, and water, 'show not only that place is something, but also that it exerts a certain influence. ${ }^{44}$ He saw this influence of place as a form of gravity that drew bodies towards certain places, places which somehow reflected that body. When a body found itself in such a place Aristotle considered that it was in its 'proper place' for 'the movement of each body to its own place is motion towards its own form. ${ }^{45}$ This location of a body in its proper place was recognized by Aristotle as a state where the body experiences a sense of wholeness and a form of stillness. ${ }^{46}$

This Aristotelian notion of place could be dismissed as the outdated views of classical physics. Aristotle's views, however, were informed not by experimentation but by his powers of observation. Today, therefore, his views on the power of place speak of the human experience of place. His thinking on how a body is drawn to its proper place, a place where it finds a sense of wholeness, completeness, and stillness, is a form of phenomenological gravity, the force that draws an individual or indeed any form of life to where they feel whole, complete, and thus find stillness. Examples of this notion of an individual in their proper place are evident in the art of portraiture where the artist seeks 
to place the individual in the setting and clothing that makes them complete and whole so that their true character is expressed. But it also extends to all levels of life, whether it is a tidy room with all things in their proper place or the chosen lifestyle of an individual which nurtures that individual with feelings of completeness and wholeness.

As an area becomes rich with cultural layers, then according to Aristotelian thinking, it will grow in its potential to influence human activity, such activity as wanting to maintain place names and taking measures to protect a storied location. Society will generally seek to maintain a tradition or protect the history of its areas, whether this is a town street, a sports stadium, or a national park. This is achieved by resisting change to that area and bringing into the area events and things which are deemed to be traditionally correct for that place. This in turn promotes stillness, stillness in the sense of a resistance to change, a level of consistency. Thus, according to Aristotle's views, a landscape can gain agency by the power of place.

\section{The song of the Beacons}

In returning to the twin summits of the Brecon Beacons, recently the area has been made into the Brecon Beacon's National Park in order to maintain its wilderness. Additionally, the whole of the Brecon Beacons has been declared a Dark Sky Area so that the brilliance of the starry sky can be returned to the region, which by default ensures that the starry dragon will not be lost to light pollution. Furthermore, some eight hundred years after Gerald wrote his story of well and fish, this, too, is being reproduced by human activity. The construction of the rectangular Upper Neuadd Reservoir reflects Gerald's magical deep square well. Gerald's claim that no spring flowed from this well is also maintained, for the reservoir is a holder of water from which no streams flow. Only pipelines and the occasional drainage are its outlet. Continuing the parallels between Gerald's well and the reservoir is the issue of the trout. Gerald claimed that in the well 'trout are said to be found there from time to time. ${ }^{47}$ The reservoir has been stocked by the Merthyr Tydifil Angling Association with brown trout, a fish considered elusive as it rarely rises to a fly so that they give the impression of 'disappearing' in the reservoir. It is almost as if the Merthyr Tydifil Anglers had intentionally followed Gerald's description of the well. There may also be good reason for the 1902 image of the proud dragon standing at the top of the plaque on the outflow of the reservoir (Figure 7.1, middle). Although placed there with Welsh 
pride by the reservoir builders, this too could be part of the place's voice. For the dragon traditionally lives in lonely and desolate spots remote from humankind, lofty with big airy skies, and often near water. ${ }^{48}$ The dragon has also crept into the promotional material of Brecon Beacon's National Park which uses a photo of two people looking at a starry sky. In the background, understandably, is Arthur's Chair, the twin peaks, but if one looks closely at the peaks, the photo just happens to have captured the dragon sitting on the ridge. ${ }^{49}$ These may be a string of coincidences, a fluke of human activity which just happens to be fulfilling the local legends around the peaks and its valleys. But if mountains have agency, then here is evidence of these mountains slowly restoring the magical habitat of the native Welsh dragon, a creature that can be viewed sitting on Arthur's Chair on dark winter nights, even in the mountain's promotional material.

There is sacredness here as well, the sacredness which comes from the power of a place to maintain itself. Its most obvious level is the natural sacredness of a high place and the quiet sacredness of a burial ground. This is sacredness which emerges from stillness as a timelessness sits upon it. Being largely deserted, it has a sense of being left alone to its own thoughts. Yi-Fu Tuan claimed that if we think of space as that which allows movement, then place is pause. ${ }^{50}$ This place requires pause. The fly-fishers have to wait for hours in the stillness as they hunt the elusive fish, hikers pause on the peak of Pen-y-Fan to savour the view and the moment, and even the water is 'paused', held back from its normal eagerness to run down the valley by the reservoir. This is a place still and wild, paused yet alive. It holds many layers of local and national stories and through the helpful hands of eager humans, it is expressing the material features of its own story. This place, to use Beldon Lane's words, 'demands its own integrity, its own participation in what it "becomes," its own voice..51

This notion of the 'voice' of a place is described by Sean Kane as 'the song of the place to itself'. Kane considers that this song is created when folklore and nature combine in an annual rhythm which 'preserves a place whole and sacred, safe from human meddling. ${ }^{52}$ In Kane's example, the annual rhythm is that of a salmon run up a river which becomes sanctified with local mythology and where salmon, myth, and forest combined as the river's song, sung not for human ears, but for the simply joy of its singing. In the case of the roof of the Brecon Beacons, the natural rhythm that produces the song is the annual winter appearance of the dragon in Arthur's Chair. Importantly, this is independent of whether this is noticed or understood or even 'heard' by humans. The song that the two mountains and the valley 'sings to itself' is a song of dragons, kings and thrones, trout, and deep wells. 
It is only our ontologies that cast landscape as an inactive canvas. Lane argued that scholarly discourse about sacred place often lacks any basis for appreciating the native traditions that nature 'talks back', that it participates in the experiences humans have of it. ${ }^{53}$ With Lane's arguments in mind, the mountains and the ridge of Arthur's Chair can be considered as 'talking back', and the evidence of this conversation with humanity is suggested in the materialization of the components of its song, the dragon's habitat being protected by the humanmaintained wildness and the human-maintained dark skies, the magical stories expressed by the human-built deep well, the human stocking of the water with elusive trout, all of which sit in a stillness which is maintained quite instinctually by the human visitors. Humanity is in conversation with these mountains.

\section{Notes}

1 Belden C. Lane, Landscapes of the Sacred: Geography and Narrative in American Spirituality, expanded ed. (Baltimore, MD: Johns Hopkins University Press, 2001), 42.

2 Carl Lofmark and G. A. Wells, A History of the Red Dragon (Llanrwst: Gwasg Carreg Gwalch, 1995), 74.

3 'Fishing in Kite Country', http://www.fishing-in-kite-country.co.uk/fishing/neuares. html (accessed 1 November 2013).

4 Jenny Hall and Paul Sambrook Trysor, 'Uplands Initiative Brecon Beacons (East) Archaeological Survey (Part One)' (The Royal Commission on the Ancient and Historical Monuments of Wales, 2009), 30.

5 An Inventory of the Ancient Monuments in Brecknock (Brycheiniog). The Prehistoric and Roman Monuments. Part 1: Later Prehistoric Monuments and Unenclosed Settlements to 1000 A.D. (London: Royal Commission on the Ancient Historical Monuments of Wales, 1997), 110-11.

6 N. W. Jones and W. J. Owen, Prehistoric Funerary \& Ritual Sites: Eastern Brecon Beacons (Cadw Welsh Historic Monuments, 2006), 26.

7 An Inventory of the Ancient Monuments in Brecknock, 117; Alex Gibson, Survey on Pen-y-Fan and Corn Du, Brecon Beacons, Powys, April-May 1990 (National Trust, 1990), 6.

8 Christopher Tilley, A Phenomenology of Landscape (Oxford: Berg, 1994), 56.

9 All field measurements were taken with a Suunto compass and clinometer by the author in October 2013 on the easterly side of the lake. This altitude measurement is approximated, as one cannot now stand on the island.

10 Cambrensis Giraldus, The Journey through Wales/the Description of Wales, trans. Lewis Thorpe (Harmondsworth: Penguin, 1978), 95. 
11 Giraldus, Journey through Wales, 96.

12 Thomas Green, Arthuriana: Early Arthurian Tradition and the Origins of the Legend (Lincolnshire: Lindes Press, 2009), 108-9.

13 Giraldus, Journey through Wales, 96.

14 Giraldus, Journey through Wales, 94.

15 Giraldus, Journey through Wales, 95.

16 Tim Ingold, Lines: A Brief History (London: Routledge, 2007), 74.

17 Aratus, Phaenomena, trans. Aaron Poochigian (Baltimore, MD: John Hopkins University Press, 2010), L.45-9.

18 Claudius Ptolemy, Ptolemy's Almagest, trans. G. J. Toomer (New Jersey: Princeton University Press, 1998), VII 5, III. H44.

19 Bernadette Brady, 'Images in the Heavens: A Cultural Landscape', in The Imagined Sky, ed. Darrelyn Gunzburg (Sheffield: Equinox, 2016), 234-58.

20 Bernadette Brady, 'Images in the Heavens: A Cultural Landscape, Journal for the Study of Religion, Nature and Culture 7 (2013): 461-84.

21 Peter Guest, 'The Early Monetary History of Roman Wales: Identity, Conquest and Acculturation on the Imperial Fringe', Britannia 39 (2008): 33-58, at 33.

22 Geoffrey of Monmouth, History of the Kings of Britain, trans. Sebastian Evans (London: J. M. Dent, 1904), 188.

23 Mark Williams, Fiery Shapes, Celestial Portents and Astrology in Ireland and Wales 700-1700 (Oxford: Oxford University Press, 2010), 108.

24 Pat Southern and Karen R. Dixon, The Late Roman Army (London: Yale University Press, 1996), 126.

25 J. S. P. Tatlock, 'The Dragons of Wessex and Wales', Speculum 8 (1933): 223-35, at 223 .

26 Tatlock, 'Dragons of Wessex and Wales', 228.

27 Ronald Hutton, 'The Early Arthur', in The Cambridge Companion to the Arthurian Legend, ed. Elizabeth Archibald and Ad Putter (Cambridge: Cambridge University Press, 2009), 21-35, at 24.

28 Gildas, 'On the Ruin of Britain', trans. J. A. Giles and T. Habington (1842), 23-4, http://www.heroofcamelot.com/historic-documents/on-the-ruin-of-britain (accessed 1 October 2013).

29 Nennius, 'Historia Brittonum', in Six Old English Chronicles, trans. J. A. Giles (London: Henry G. Bohn, 1848), Section 42, http://www.bsswebsite.me.uk/History/ Nennius/NenniusHistory2.html - (accessed 12 October 2013).

30 Revelation 12:3, 12:9.

31 Ronald Hutton, The Pagan Religions of the Ancient British Isles: Their Nature and Legacy (Oxford: Blackwell, 1991), 125-6.

32 Monmouth, History of the Kings of Britain, 292; Marged Haycock, Legendary Poems from the Book of Taliesin (Aberystwyth: CMCS, 2007), 503. 
33 Jeffrey Gantz, The Mabinogion, trans. Jeffrey Gantz (Harmondsworth: Penguin, 1976), 184-5.

34 Tatlock, 'Dragons of Wessex and Wales', 229.

35 Hutton, 'Early Arthur', 28.

36 Thomas Green, Concepts of Arthur (Stroud: Tempus, 2007), 188.

37 Green, Concepts of Arthur, 188.

38 Gertude Jobes and James Jobes, Outer Space: Myths, Name Meanings, Calendars (New York: Scarecrow, 1964), 260.

39 Paul Kunitzsch and Tim Smart, A Dictionary of Modern Star Names (Cambridge: Sky, 2006), 19.

40 Tilley, Phenomenology of Landscape, 24.

41 Aristotle, 'Physics', in The Complete Works of Aristotle, Volume 1, ed. Jonathan Barnes, trans. R. P. Hardie and R. K. Gaye (Princeton, NJ: Princeton University Press, 1984), 315-446: 4.2, 209a 8-9, at 32-3.

42 Edward S. Casey, The Fate of Place: A Philosophical History (Berkeley: University of California Press, 1998), xii, 51-3.

43 Casey, Fate of Place, 70.

44 Aristotle, 'Physics', 208 b11.

45 Aristotle, 'On the Heavens', in The Complete Works of Aristotle, Volume 1, ed. Jonathan Barnes, trans. J. L. Stocks (Princeton, NJ: Princeton University Press, 1984), 447-511: IV 3, 310a, at 35.

46 Aristotle, 'Metaphysics', in The Complete Works of Aristotle, Volume 2, ed. Jonathan Barnes, trans. R. P. Hardie and R. K. Gaye (Princeton, NJ: Princeton University Press, 1984), 1552-728: IV, 1014b, at 16-26.

47 Giraldus, Journey through Wales, 96.

48 Lofmark and Wells, History of the Red Dragon, 24-5.

49 Brecon Beacons, Our National Park, Ten Places to Go Stargazing, http://www. breconbeacons.org/stargazing-ten-places (accessed 12 August 2017).

50 Yi-Fu Tuan, Space and Place: The Perspective of Experience (London: Arnold, 1977), 6.

51 Belden C. Lane, Landscapes of the Sacred: Geography and Narrative in American Spirituality, expanded ed. (Baltimore, MD: Johns Hopkins University Press, 2001), 4.

52 Sean A. Kane, Wisdom of the Mythtellers (Ontario: Broadview Press 1998), 46, 50.

53 Lane, Landscapes of the Sacred, 41.

\section{Bibliography}

An Inventory of the Ancient Monuments in Brecknock (Brycheiniog). The Prehistoric and Roman Monuments. Part 1: Later Prehistoric Monuments and Unenclosed Settlements 
to 1000 A.D. London: Royal Commission on the Ancient Historical Monuments of Wales, 1997.

Aratus, Phaenomena, translated by Aaron Poochigian. Baltimore, MD: John Hopkins University Press, 2010.

Aristotle. Metaphysics. In The Complete Works of Aristotle, volume 2, edited by Jonathan Barnes, translated by R. P. Hardie and R. K. Gaye, 1552-728. Princeton, NJ: Princeton University Press, 1984.

Aristotle. On the Heavens. In The Complete Works of Aristotle, Volume 1, edited by Jonathan Barnes, translated by J. L. Stocks, 447-511. Princeton, NJ: Princeton University Press, 1984.

Aristotle. Physics. In The Complete Works of Aristotle, volume 1, edited by Jonathan Barnes, translated by R. P. Hardie and R. K. Gaye, 315-446. Princeton, NJ: Princeton University Press, 1984.

Brady, Bernadette, 'Images in the Heavens: A Cultural Landscape.' Journal for the Study of Religion, Nature and Culture 7 (2013): 461-84.

Brady, Bernadette. 'Images in the Heavens: A Cultural Landscape. In The Imagined Sky, edited by Darrelyn Gunzburg, 234-58. Sheffield: Equinox, 2016.

Brecon Beacons, Our National Park, Ten Places to Go Stargazing, http://www. breconbeacons.org/stargazing-ten-places (accessed 12 August 2017).

Casey, Edward S. The Fate of Place: A Philosophical History. Berkeley: University of California Press, 1998.

'Fishing in Kite Country', http://www.fishing-in-kite-country.co.uk/fishing/neuares. html $>$ (accessed 1 November 2013).

Gantz, Jeffrey. The Mabinogion, translated by Jeffrey Gantz. Harmondsworth: Penguin, 1976.

Gibson, Alex. 'Survey on Pen-Y-Fan and Corn Du, Brecon Beacons, Powys, April-May 1990'. National Trust, 1990.

Gildas, 'On the Ruin of Britain', translated by J. A. Giles and T. Habington, 1842, http:// www.heroofcamelot.com/historic-documents/on-the-ruin-of-britain (accessed 1 October 2013).

Giraldus, Cambrensis. The Journey through Wales/the Description of Wales, translated by Lewis Thorpe. Harmondsworth: Penguin, 1978.

Green, Thomas, Concepts of Arthur. Stroud: Tempus, 2007.

Green, Thomas. Arthuriana: Early Arthurian Tradition and the Origins of the Legend. Lincolnshire: Lindes Press, 2009.

Guest, Peter. 'The Early Monetary History of Roman Wales: Identity, Conquest and Acculturation on the Imperial Fringe'. Britannia 39 (2008): 33-58.

Hall, Jenny, and Paul Sambrook Trysor. 'Uplands Initiative Brecon Beacons (East) Archaeological Survey (Part One)'. The Royal Commission on the Ancient and Historical Monuments of Wales, 2009.

Haycock, Marged. Legendary Poems from the Book of Taliesin Aberystwyth: CMCS, 2007. 
Hutton, Ronald. The Pagan Religions of the Ancient British Isles: Their Nature and Legacy. Oxford: Blackwell, 1991.

Hutton, Ronald. 'The Early Arthur'. In The Cambridge Companion to the Arthurian

Legend, edited by Elizabeth Archibald and Ad Putter, 21-35. Cambridge: Cambridge University Press, 2009.

Ingold, Tim. Lines: A Brief History. London: Routledge, 2007.

Jobes, Gertude, and James Jobes. Outer Space: Myths, Name Meanings, Calendars.

New York: Scarecrow, 1964.

Jones, N. W., and W. J. Owen. 'Prehistoric Funerary \& Ritual Sites: Eastern Brecon

Beacons.' Cadw Welsh Historic Monuments, 2006.

Kane, Sean A. Wisdom of the Mythtellers. Ontario: Broadview Press, 1998.

Kunitzsch, Paul, and Tim Smart. A Dictionary of Modern Star Names. Cambridge:

Sky, 2006.

Lane, Belden C., Landscapes of the Sacred: Geography and Narrative in American

Spirituality, expanded ed. Baltimore, MD: Johns Hopkins University Press, 2001.

Lofmark, Carl, and G. A. Wells. A History of the Red Dragon. Llanrwst: Gwasg Carreg Gwalch, 1995.

Geoffrey of Monmouth. History of the Kings of Britain, translated by Sebastian Evans.

London: J. M. Dent, 1904.

Nennius. 'Historia Brittonum'. In Six Old English Chronicles, translated by J. A. Giles.

London: Henry G. Bohn, 1848, http://www.bsswebsite.me.uk/History/Nennius/

NenniusHistory2.html (accessed 12 October 2013).

Ptolemy, Claudius. Ptolemy's Almagest, translated G. J. Toomer. New Jersey: Princeton University Press, 1998.

Southern, Pat, and Karen R. Dixon. The Late Roman Army. London: Yale University Press, 1996.

Tatlock, J. S. P. 'The Dragons of Wessex and Wales'. Speculum 8 (1933): 223-35.

Tilley, Christopher. A Phenomenology of Landscape. Oxford: Berg, 1994.

Tuan, Yi-Fu. Space and Place: The Perspective of Experience. London: Arnold, 1977. Williams, Mark. Fiery Shapes, Celestial Portents and Astrology in Ireland and Wales 700-1700. Oxford: Oxford University Press, 2010. 